\title{
Women in Corporate World: Walking the Tight Rope
}

\author{
Dr Gayatri Phadke ${ }^{*}$, Sharda Ratna Sitaraman ${ }^{2}$
}

\section{ABSTRACT}

In this article, we bring to you different aspects of gender stereotyping and its deeper implications on women working in the corporate. The study conformed to Double-Bind Dilemma for Women in Leadership: Damned if You Do, Doomed if You Don't, Catalyst series sponsored by IBM Corporation, which also examined barriers to women's advancement, and indicated how gender stereotypes can create several predicaments for women leaders. It indicated how cultural conditioning and unintended biases at workplace seemed to playing a big role in gender stereotyping. The study also indicated that the dilemma of double bind affected not only the perceptions of others, but also perceptions of women themselves, leading to a confusion in the style of leadership to be adopted at workplace, and reduced confidence in their selves. Many women respondents also attributed the underestimation of their capability to their upbringing, and socio-cultural factors that pre-determined the superiority of men over women in society leading to women 'belittling' themselves in some manner.

Keywords: Women Leadership, Double Bind, Gender Stereotypes, Barriers to Advancement

Frank Flynn, Professor at the Stanford Graduate Business School, shared with his class, a Harvard Business School case-study which was about a real life Silicon Valley entrepreneur named Ms. Heidi Roizen. He divided his class into two groups - one group received the original version, and the second group received a version with the protagonist's name changed to "Howard" Roizen.

In the case, both Mr. Howard and Ms. Heidi worked at Apple. Prior to joining Apple, they had launched their own software company and have been a partner at a venture capital firm in Silicon Valley. They were proficient networkers and had well-established people, like Bill Gates, in their social circle.

\footnotetext{
${ }^{1}$ Senior Practice Consultant, Leadership, HR and Organization Development at Tata Management Training Center, Pune, India

${ }^{2}$ Researcher- Diversity and Inclusion and Human Resources at Tata Management Training Center, Pune, India *Responding Author

(C) 2016 Phadke G, Sitaraman S; licensee IJIP. This is an Open Access Research distributed under the terms of the Creative Commons Attribution License (http://creativecommons.org/licenses/by/2.0), which permits unrestricted use, distribution, and reproduction in any Medium, provided the original work is properly cited.
} 


\section{Women in Corporate World: Walking the Tight Rope}

Before the class commenced, Flynn asked the students to go online and rate their impressions of "Roizen" on several personality dimensions.

The results showed that students were harsher on Heidi than on Howard across the board. They thought Howard to be an excellent person for any company to employ as he was a go-getter and had a likeable personality to top it. Students said they found Heidi less humble and more power hungry and self-promoting than Howard. However, when students were asked to review the actual protagonist, "Heidi" Roizen, Flynn recalls, “Although they thought she’s just as competent and effective as Howard, they didn’t like her, they wouldn’t hire her, and they wouldn't want to work with her. They judged her to be selfish and less desirable than Howard; they disliked Heidi's aggressive personality. The more assertive they thought Heidi was, the more harshly they judged her”.

Are you able to relate to this story? Do you find people around you making different attributions to the same set of behaviors, exhibited by a man and a woman? Or do you think this study by Flynn is a passé?

The above situation begs a pertinent question - why should there be any difference in perception between the working style of a man and a woman, rather than appreciating the role women are expected to play?

\section{Gender Stereotyping: Evolution of the Concept}

The United Nations Human Rights explain Gender Stereotyping as a generalised view or preconception about attributes or characteristics that are, or ought to be, possessed by, or the roles that are, or should be, performed by women and men. It refers to the practice of ascribing to an individual woman or man, specific attributes, characteristics, or roles by reason only of her or his membership in the social group of women or men.

During Vedic times, (2nd Millennia BCE) women and men shared equal status in the society. Anthropological evidences show that men and women were equal in authority and power, even though they had different responsibilities. However, intensive agriculture and warfare changed this equation, as a result, woman's status in the society suffered deep erosion - women were expected to manage homes whereas men became the sole bread earners. This thought echoed in the early leadership theories as well. For instance, the 19th century's idea of "Great Man Theory of Leadership," stated that "Great leaders are born, not made". The term "Great Man" symbolised leadership primarily as a male quality, especially in the context of military leadership. It considered all men possessing certain universal characteristics that made them leaders; the original conception of leader- ship assumed that the leadership traits were largely inborn, universal, and fixed (Hollander \& Offermann, 1990). Historian Thomas Carlyle was greatly 


\section{Women in Corporate World: Walking the Tight Rope}

influenced by this theory of leadership, and at one point stated that, "The history of the world is but the biography of great men."

By 1940s, this theory was replaced by situational leadership that emphasized on the context and different leadership styles appropriate for different settings and tasks. In 1980s, Riger\&Galligan, brought forth focus on personality characteristics and behavior patterns attributed to women for low jobs in the workforce. Harragan (1977), Games Mother Never Taught you: Corporate Gamesmanship for Women noted that, if women wanted to succeed, it was time for them to learn to act more like men and play the male games that they did not participate in as kids. Their submission was that women were not capable of competing with men and the solution was to develop new skills that would allow women to succeed in leadership positions. Using an analogy between the corporate world and a foreign country, Hennig and Jardim advised women to learn the 'language and customs of this male realm', if they wished to stay on.

While the above theorists make a point on how women need to change themselves, Rosabeth Moss Kanter (1977), In Men and Women of the Corporation, attributed women's lack of success to the unequal distribution of opportunity and power, and not to the inherent gender differences. According to Kanter, women occupying positions of little influence or of little opportunity for advancement led them to behave the way they did. In the 1990s, in 'Psychological Bulletin', Eagly \& Johnson, through a meta-analysis highlighted that women are concerned with both maintenance of interpersonal relationships and task accomplishment. This finding confirms as well as refutes the stereotypical view of women as leaders (conventional wisdom holds women to be more concerned with relationships than task accomplishment). Long et. al(1993) stressed that women tend to use the task engrossed/ person invested management style, while men use the image-engrossed/ autonomy invested management style, a similar proposition put forth by Statham in 1987 who pointed that these differences leads to tremendous misunderstandings between men and women in the workplace.

Tannen (1990) held a similar view that men and women generally valued different things as they are were subjected to different experiences while growing up-men were always taught to treasure status, independence, and individual power; whereas women were taught to focus on value connection, interdependence, and power of community. This led to differences in the communication styles of men and women seemingly giving rise to misunderstandings in the workplace. This difference in upbringing led to substantial bias against women in the workplace ${ }^{\mathrm{i}}$. Bass (1981) identified, that 'stereotypes' had their effects on behavior. Women were expected to be more submissive by nature, and men were seen to have trouble taking orders from women. Women leaders were seen to be in conflict with themselves while facing divergence in what was expected of them in their roles as managers and in their roles as women. Further research explored why women were represented as minority at the board level. The double bind ${ }^{\text {ii }}$ 


\section{Women in Corporate World: Walking the Tight Rope}

stemming from gender role stereotyping in Corporate remains an issue of continuous debate and research in the fields of psychology, management, and sociology.

\section{Walking the Tight Rope- The Double Bind Predicament: What does the Literature say?}

Men have been often considered to be imbibed with traits reflecting leadership qualities: assertiveness, task- orientation, independence, competitiveness, confidence, risk taking, and having strong emotional control are considered to be masculine traits. With the legacy of gender stereotyping continuing over the decades, women have struggled to strike a balance between these masculine traits and their natural feminine characteristics such as being collaborative, having interpersonal sensitivity, empathy, and caring, to mention a few. Women reflecting these feminine qualities in the workplace have been highly liked but not respected or considered to be competent as leaders in the workplace. They were judged as being too soft, emotional and unassertive to make tough calls and project the necessary "presence" in positions of authority (Catalyst, 2007, Eagly and Carli, 2007). In contrast, women who adopted masculine traits have been respected, but not liked. They were seen as domineering, strident and unapproachable.

The challenge therefore is two-fold: to be considered as leader, women need to conform to the collective expectations of what makes a leader, and at the same time, remain true to certain gender expectations. If their behavior conforms to the gender stereotype then it is thought to be lacking as incongruent with the leader archetype; on the other hand if it reflects the leader's prototype, then people find it lacking in authenticity and is considered as improper for a woman to possess.

\section{Androgynous style of leadership: an outcome of the Double Bind Predicament}

The double bind dilemma led several researchers debating on the suitable style of leadership to be adopted at work. In their meta-analysis, Eagly and Johnson indicated that women tended to adopt a more democratic or participative style, and men tended to adopt a more autocratic or directive style. In a research study - The Qualities That Distinguish Women Leaders conducted by Caliper, a Princeton-based management consulting firm18, confirmed that women bring in distinct personality and motivational strengths to leadership. They have an open, consensusbuilding, collegial approach to leading. Results indicated that women leaders are assertive, persuasive, empathic, willing to take risks, outgoing, flexible and have a need thrust to towards getting get things done. Herb Greenberg, Ph.D., President and Chief Executive Officer of Caliper, concludes, "These personality qualities combine to create a leadership profile that is much more conducive to today's diverse workplace, where information is shared freely, collaboration is vital and teamwork distinguishes the best companies”

Bem (1974) coined the concept of 'Androgyny' - a combination of both male and female qualities. An androgynous individual is someone who is independent and tender, aggressive and gentle, assertive and yielding, and masculine and feminine at the same time19. Research 


\section{Women in Corporate World: Walking the Tight Rope}

positively emphasized this effective, androgynous style as transformational leadership, which encompasses several interrelated types of behaviors (Avolio, 2010; Bass, 1998). On-field research also indicated successful women executives using a blend of masculine and feminine behavioral styles: they are not afraid to be direct, authoritative and to lead by example; at the same time, they know when to be nurturing, open and inclusive.

Kilden Information Centre for Gender Research in Norway in 2013 revealed marginal differences between the leadership styles adopted by male and female leaders. The study demonstrated that an androgynous leader- ship style is most effective in achieving a climate for innovation.

The changing times, however, have begun to focus beyond androgyny and recognized that both genders have an important role to play at the workplace. The grouping now is "people," not "male versus female." This recognition of diversity is said to allow the leaders to lead in ways that will draw upon their individual strengths. The concept of "think manager- think male" is diminishing with time as more and more women are getting onto commendable positions in the corporate. Burns, back in 1978, had written "when women are accepted as leaders, men will change their own leadership styles". With men playing a vital role in restructuring of the workplace, there is a growing consciousness among the male members that their options have also been limited by societal standards about 'male' behavioriii. Dr. Anne Perschel, leadership psychologist, echoed similar thought as Burns. "The male bias is reflected in a false conception of leadership as mere command and control. As leadership comes properly to be seen as a process of leaders engaging and mobilizing the human needs and aspirations of followers, women will be more readily recognized as leaders and men will change their own leadership styles”.

\section{RESEARCH METHODOLOGY}

Out study is an attempt to understand the perception of organizations, about women, particularly stemming from gender stereotyping, and therefore the challenges thus faced by them.

For our study, we interviewed 21 senior women leaders, holding positions as General Manager and above, on various challenges they faced particularly because of gender. We also included 50 women from middle management to understand nuances of gender stereotyping at work. The women interviewed were from different Tata group companies, working in different functions.

\section{Research Question}

We posed two questions to the interviewees -

1. What according to them were different aspects of gender stereotyping?

2. What characteristics or traits they portrayed while climbing the corporate ladder, which was not received well at the workplace by their team members. 


\section{RESEARCH RESULTS}

One of the top concerns that came out of the interviewees was,

That being emotional at workplace was always seemed to be held against them. Their male counterparts considered displaying of emotions as unprofessional and as an inability to handle stressful situations.

This resonates with the theory that F. Ralston put forth on expressing emotions at work place. According to him, expressing emotions are often considered to be shameful, uncivilized and messy.

The Double-Bind Dilemma for Women in Leadership: Damned if You Do, Doomed if You Don't, Catalyst series sponsored by IBM Corporation, also examined barriers to women's advancement, and indicated how gender stereotypes can create several predicaments for women leaders. Those women are evaluated against a "masculine" standard of leadership; the predicaments, all of which put women in a double bind and can potentially undermine their leadership. As an individual, a woman goes through a feeling of intuitive discom- fort while sharing her true reactions and feelings with others. Her being compassionate and emotionally involved is considered as interference with decision-making process, as corroborated with the Predicament 1, ‘Extreme Perceptions Too Soft, Too Tough, and Never Just Right’ (See Box)

\section{Predicament 1: Extreme Perceptions Too Soft, Too Tough, and Never Just Right}

When women act in ways that are consistent with gender stereotypes, they are viewed as less competent leaders. When women act in ways that are inconsistent with such stereotypes, they are considered unfeminine.

Predicament 2: The High Competence Threshold Women leaders face higher standards and lower rewards than male leaders.

Women leaders are subjected to higher competency standards. On top of doing their job, women must prove that they can lead over and over again and constantly manage stereotypical expectations.

Predicament 3: Competent but Disliked

Women leaders are perceived as competent or liked, but rarely both.

Another input that from a senior interviewee was, Exhibiting a collaborative and soft approach labelled her 'as 'weak' and unlikely of a typical leader'. However when the respondent exhibited a go-getter, task oriented attitude at the workplace, she was not favored and was seen demanding, pushy and lacking in empathy.

The above comment conforms to Predicament 3 in the 'Double-Bind Dilemma for Women in Leadership: Damned if You Do, Doomed if You Don’t'. (See Box above) where women leaders 


\section{Women in Corporate World: Walking the Tight Rope}

were being either liked or considered competent. Competent yet liked, was a combination often unseen.

To add to the above, below are some of senior women leader's respondent's inputs, Delna Avari, Ex - Head (Marketing Communication and Services), Tata Motors:

"Women need to work harder than male counterparts to prove. I was always conscious of the fact that whatever I am doing, everyone is looking; everyone is watching, how I am behaving. Every action of mine is getting way more amplified than I would like. This holds back a lot of women taking on assignments; you don't want to jump in as a lady and fail and because your failures are amplified so much you know you are scared to take those chances”-

Rajeshwari Srinivasan, Associate Vice President \& Regional Business Head, Titan Company Limited also validated this thought:

"The biggest challenge is being able to prove yourself without bringing in stereotype masculine qualities ... Being able to be assertive without being aggressive”.

Such experiences were reported repeatedly by the senior women we spoke to, validating the theory that women need to prove to lead, over and over again, and constantly manage stereotypical expectations, supported by Predicament 2 (See Box above)

These women further added that...

They have to face consequences of having to balance life both at the professional and personal fronts. Their need to juggle between these two lives and give in their best to both have not only created issues - like being considered not serious about work- but also have resulted in lower self-esteem.

"Need to rush back home from work to manage the home front was looked upon as not being serious about work, hence I had been requesting for flexi-time benefits”, says an- Ex-Vice President, of a Tata Group company.

Cultural conditioning and unintended biases at workplace seemed to playing a big role in the issues high- lighted by the respondents.

Richa Arora, Chief Operating Officer, Tata Chemicals seconded the views by saying, "If there is a set of traits in a male leader and the same traits are displayed by a women leader, they tend to be viewed very differently. If a man at the senior level would get into the details of things he is usually perceived to be a hands-on, analytical person; however the same set of traits 


\section{Women in Corporate World: Walking the Tight Rope}

exhibited by a woman can be viewed negatively, and she is seen as getting unnecessarily into the nitty-gritty of things!”

In the double bind dilemma, another trait that often leads women to struggle is balancing being aggressive versus being assertive. Almost all the women we interacted with repeatedly emphasized upon the discomforting situation they had to face while trying to be assertive. Instead, they were perceived as aggressive and exhibiting a behavior deemed as misfit for a woman.

Says Nupur Roy Chowdhury, Head of Strategy, Tata Global Beverages,

"Sometimes, when women are quietly assertive, it is not taken in the right spirit; they (the co-workers) would prefer you to be a little loud, a little aggressive in meetings. This perhaps, doesn't come naturally to many women”.

Reiterating the above Delna Avari, points out,

"If I am strong about something I will be seen as - Oh! She is so aggressive. It's not seen as being assertive or result oriented".

While some women have learnt to ignore such perceptions and worries about how they would be viewed by the management and team members, it has led few other women to hold themselves back from moving ahead.

In addition to the above, during our discussion with the women leaders, we found that the dilemma of double bind affected not only the perceptions of others, but also perceptions of women themselves, leading to a confusion in the style of leadership to be adopted at workplace, and reduced confidence in their selves.

In some of our interactions, albeit not all, a strand of thought resonated that some women often tended to underestimate their own leadership capabilities for a variety of reasons. They attributed the societal stereo- typing to proscribe their belief in themselves as leaders.

Minari Shah, Head - Corporate Communications, Tata Motors supported this thought, "Social norms insist on women to be underplayed, but then they seem to get penalised if they are seen as hesitant or diffident in a corporate environment".

The undercurrent of thought is that predisposition of the societal norms expects them to conform to certain behavioral and gender specific norms. This apparently leads them to doubt their own leadership abilities. The leaders also confirmed that the need to balance their work-life patterns with their home demands had left them undecided on what to concentrate and how to balance, thereby affecting their trust in their own abilities. 


\section{Women in Corporate World: Walking the Tight Rope}

Few women in senior managerial positions also backed this thought of underestimation of women currently climbing up the career ladder. Being unsure of the possibilities of their growth as there are none or very few role models to look up to, is a bottleneck women face while charting their career path.

Tripti Srivastava, Head- Business Performance Enhancement - Operations, Tata Steel chimes "Before exploring the limit to the fullest, they have just said that they can't do that and that has often been a barrier in their career life”.

The women felt that they had to continuously prove that they were deserving candidates for the leadership suite and this constant need to justify themselves had led them to doubt their selfability as leaders.

One senior woman leader raised an interesting, yet contrary point that,

"While we as women tend to at times doubt our ability to take on bigger and challenging assignments, the men also feel so from time to time. However the difference lies in the attitude of men towards this. Men have a tendency to "fake it till you make it", while women more often are seen to opt out”.

Delna Avari, delves into a similar explanation by pointing out an internal research conducted by HP advocates on women applying for job vacancies.

"Women are just too scared to put up their hands for roles. As a matter of fact when a man looks at a role, and if he is 60-70\% ready, he puts up his hand; whereas a woman looks at a role and wants to be 95 percent ready before she puts up her hand for it”.

Delna asserts that such a behavior is often attributed to the amplification effect that comes in with being a woman and a leader simultaneously. "They don't want to jump in as a lady and fail as the failure tends to get amplified so much that one is scared to take those chances, and in the process women lose out on big opportunities to change”.

Many women respondents also attributed the underestimation of their capability to their upbringing, and socio-cultural factors that pre-determined the superiority of men over women in society leading to women 'belittling' themselves in some manner. The need imposed by the society on women to act in a particular way and the call of the hour to respond in a particular way at the workplace was pointed as factors putting stress on women to be confused and underestimate their leadership abilities. 


\section{Women in Corporate World: Walking the Tight Rope}

Lack of exposure to opportunities like grooming, and training also contributed to the feeling of being unsure of their capabilities, according to the respondents. The women leaders. As women by nature in general, are little reticent, the women leaders stressed on adequate grooming and training, to give women employees important and challenging assignments and an opportunity to prove themselves at the workplace.

As one respondent said, "Only when more and more women would succeed, they would be cognizant of their ability. Only then woman would approve of herself - I know that I can'”.

\section{CONCLUSION}

In this fast moving world where competition is stiff and growth opportunities up for grabs, it is time for women to learn to keep their hands up. For women who choose not to come forward, even managers with the best intentions might not notice them.

Institutions and individuals need to notice and correct this behavior by encouraging, promoting, and championing more women at the workplace. Sheryl Sandberg in her book 'Lean In' encourages women to "sit at the table," seek challenges, take risks, and pursue their goals with gusto.

While literature has time and again pointed out the role men need to play in being equal partners to alleviate gender inequality, organizations and individuals too need to consciously get over what social scientists call a "bias blind spot?"

Thinking that in the corporate as leaders we are objective can actually make the situation worse. It makes people so confident about their own powers of objectivity that they fail to correct their bias of gender stereo- typing in leadership. Organizations need to be vigilant with the attributions they make regarding the same set of behaviors when they are portrayed by a man or a woman. Once men and women in the corporate admit and discuss these biases, steps to counteract them would naturally follow.

Finally as pointed out by one senior woman leader, "people often use the phrase 'working woman', 'woman manager', woman CEO' to indicate women, but such are not used for men. Use of these phrases perpetuate certain gender specific beliefs and encourage people to look at women in workplace through the lens of 'women leaders'. It is important to create the perspective of being an individual at the workplace and move away from the men versus woman ideologies”.

As aptly pointed out by Richa Arora, "the moot question remains 'Is discussing women at workplace to sensitize people or is it make people view women even more differently?' 


\section{Women in Corporate World: Walking the Tight Rope}

\section{Acknowledgments}

The author appreciates all those who participated in the study and helped to facilitate the research process.

\section{Conflict of Interests}

The author declared no conflict of interests.

\section{REFERENCES}

Avolio, B. J. (2010). Full range leadership development (2nd ed.). Thousand Oaks, CA: Sage in Eagly. H. Alice, Women as Leaders: Leadership Style Versus Leaders' Values and Attitudes, 2013, in Research Symposium: Challenging Conventional Wisdom \& Gender Work

Bass, B. M. (1998). Transformational leadership: Industry, military, and educational impact. Mahwah, NJ: Erlbaum in Eagly.H. Alice, Women as Leaders: Leadership Style Versus Leaders’ Values and Attitudes, 2013, in Research Symposium: Challenging Conventional Wisdom \& Gender Work

Bem, S.L. (1974), The Roles that Women Play in Davidson, M.J.; Cooper, C.L, (1992),Shattering The Glass Ceiling; The Woman Manager, Paul Chapman Publishing Ltd, London, ISBN 1-85396-132-9, Page 95

Caliper Research and Development Department (2014) Women Leaders Research PaperQualities that Distinguish Women Leaders, Reserved from, https://www.calipercorp.com/portfolio/the-qualities-that-distinguish-women-leaders/ [July 01, 2016, 09:33 AM]

Catalyst (2007), The Double-Bind Dilemma for Women in Leadership: Damned if You Do, Doomed if You Don't, Reserved from, http://www.catalyst.org/system/files/The_Double_Bind_Dilemma_for_Women_in_Leade rship_Damned_if_You_Do_Doomed_if_You_Dont.pdf [June 02, 2016, 12:30 AM]

Cherry, K, (2016), The Great Man Theory of Leadership, Reserved from, http://psychology.about.com/od/leadership/a/great-man-theory-of-leadership.htm [October 16, 2016, 02:34 PM]

Dishman, L, The gender divide and the traits of effective leadership: who comes out on top?, Reserved from, http://www.fastcompany.com/3030754/the-future-of-work/the-genderdivide-and-the-traits-of-effective-leadership-who-comes-out-on [August 11, 2016, 09:33 AM]

Double Bind: If a woman behaves in a "feminine" way, she may be liked, but she may not be respected or seen as a leader. If she operates in a "masculine” way, however, she may be judged and disliked, Reserved from, http://www.huffingtonpost.com/entry/obstacles-forwomen-in-bu_b_5432624.html?section=india [June 02, 2016, 10:30 AM]

Eagly, A. H., Johannesen-Schmidt, M. C., \& van Engen, M. (2003). Transformational, transactional, and laissez-faire leadership styles: A meta-analysis comparing women and men, Psychological Bulletin in Eagly. H. Alice, Women as Leaders: Leadership Style 


\section{Women in Corporate World: Walking the Tight Rope}

Versus Leaders' Values and Attitudes, 2013, in Research Symposium: Challenging Conventional Wisdom \& Gender Work

Eagly, A; Carli, L, (2007), Through the Labyrinth: The Truth about how Women Become Leaders, Harvard Business Review Press, ISBN-10: 1422116913 Page 32

Eagly, A; Carli, L, (2007), Through the Labyrinth: The Truth about how Women Become Leaders, Harvard Business Review Press, ISBN-10: 1422116913 Page 32

Gender stereotypes/stereotyping, Reserved from, http://www.ohchr.org/EN/Issues/Women/WRGS/Pages/GenderStereotypes.aspx [October 16, 2016, 10:12 AM]

Gender-Related Material in the New Core Curriculum, Reserved from, https://www.gsb.stanford.edu/stanford-gsb-experience/news-history/gender-relatedmaterial-new-core-curriculum [May 16, 2016, 10:32 AM]

Great Man Theory. Reserved from, http://www.leadership-central.com/great-man-theory.html\#axzz49NwamC9W [October 16, 2016, 02:38 PM]

Harragan, B, (1977), Games Mother Never Taught you: Corporate Gamesmanship for Women, Warner Books, ISBN-10: 0446329037, in Wenniger, M; Mary Helen Conroy, M, (2001), Gender Equity or Bust!: On the Road to Campus Leadership with Women in Higher Education, Jossey-Bass, ISBN-10: 0787952842, Page- 15

Heidi Roizen: Networking is more than collecting lots of names, Stanford Business, (Nov 1, 2009), Reserved from, https://www.gsb.stanford.edu/insights/heidi-roizen-networkingmore-collecting-lots-names[May 16, 2016, 11:02 AM]

Moran B.B. (1992) Gender Differences in Leadership, LIBRARY TRENDS, Vol. 40, No. 3, Winter 1992, University of Illinois, Page 479-488, Reserved from, https://www.ideals.illinois.edu/bitstream/handle/2142/7791/librarytrendsv40i3h_opt.pdf? sequ [October 15, 2016, 02:00 PM]

Moran B.B. (1992) Gender Differences in Leadership, LIBRARY TRENDS, Vol. 40, No. 3, Winter 1992, University of Illinois, Page 479-488,

Moran B.B. (1992) Gender Differences in Leadership, LIBRARY TRENDS, Vol. 40, No. 3, Winter 1992, University of Illinois, Page 487, Reserved from, https://www.ideals.illinois.edu/bitstream/handle/2142/7791/librarytrendsv40i3h_opt.pdf? sequ [July 01, 2016, 09:33 AM]

Ralston, F, (1995), Hidden Dynamics: How Emotions Affect Business Performance \& How You Can Use Their Power For Positive Results, AMACOM, ISBN-10: 0814402720, Page 110-135 Reserved from, https://www.ideals.illinois.edu/bitstream/handle/2142/7791/librarytrendsv40i3h_opt.pdf? sequ [October 15, 2016, 02:00 PM]

Sandberg, S. (2013), Sit at the Table in Lean In: Women, Work and the Will to Lead, WH Allen, ISBN-10: 0385349947, Page. 27- 38. Page 141-159 


\section{Women in Corporate World: Walking the Tight Rope}

Solberg, G.A.; et al. (2013) Male and Female Leadership Styles, in The British Psychological Society, Reserved from, http://www.bps.org.uk/news/male-and-female-leadership-styles [July 05, 2016, 09:33 AM]

This is a study on the personality qualities in a woman and man and motivational factors which are at the core of the underlying gender differences

Tips for Managers, Reserved from, http://leanin.org/together/ui/pages/tips/pdfs/tips-formanagers.pdf [July 01, 2016, 11:45 AM]

Virginia E. Schein, Marilyn J. Davidson (1993) Think Manager, Think male, Management Development Review, Vol. 6 Issue: 3

Women, Work, and Coping: A Multidisciplinary Approach to Workplace Stress, by Bonita Clarice Long, Sharon E. Kahn, UBC Academic Women's Association, Canadian Centre for Policy Alternatives, McGill-Queen's Press - MQUP, 1993

How to cite this article: Phadke G, Sitaraman S (2016), Women in Corporate World: Walking the Tight Rope, International Journal of Indian Psychology, Volume 4, Issue 1, No. 82, ISSN:2348-5396 (e), ISSN:2349-3429 (p), DIP:18.01.145/20160401, ISBN:978-1-365-59365-9 